\title{
Erratum to: Contribution of discourse and morphosyntax skills to reading comprehension in Chinese dyslexic and typically developing children
}

\author{
Pakey Pui-man Chik • Connie Suk-han Ho • \\ Pui-sze Yeung • Yau-kai Wong • David Wai-ock Chan • \\ Kevin Kien-hoa Chung • Lap-yan Lo
}

Published online: 1 December 2011

(C) The International Dyslexia Association 2011

\section{Erratum to: Ann. of Dyslexia DOI 10.1007/s11881-010-0045-6}

In the article, "Contribution of discourse and morphosyntax skills to reading comprehension in Chinese dyslexic and typically developing children," some of the references in the text and in the reference list were published erroneously.

The online version of the original article can be found at http://dx.doi.org/10.1007/s11881-010-0045-6.

P. P.-m. Chik

Faculty of Education, The Chinese University of Hong Kong, Shatin, N. T., Hong Kong,

People's Republic of China

e-mail: pakeychik@cuhk.edu.hk

C. S.-h. Ho $(\bowtie) \cdot$ P.-s. Yeung $\cdot$ Y.-k. Wong

Department of Psychology, The University of Hong Kong, Pokfulam Road, Hong Kong,

People's Republic of China

e-mail: shhoc@hkucc.hku.hk

P.-s. Yeung

e-mail: patcyy@hkucc.hku.hk

Y.-k. Wong

e-mail: herrick@hku.hk

D. W.-o. Chan

Department of Educational Psychology, Faculty of Education, The Chinese University of Hong Kong, Hong Kong, People's Republic of China

e-mail: davechan@e.cuhk.edu.hk

\section{K. K.-h. Chung}

Department of Special Education and Counselling, The Hong Kong Institute of Education, Hong Kong, People's Republic of China

e-mail: kevin@ied.edu.hk

L.-y. Lo

Department of Counselling and Psychology, Hong Kong Shue Yan University, Wai Tsui Crescent, Braemer Hill, North Point, Hong Kong, People's Republic of China

e-mail: lylo@hksyu.edu 
The corrected reference citations in the text are as follows:

On the second page, in the Introduction, second paragraph, second line, Leong, Hau, Tse, \& Loh 2008 should read Leong, Tse, Loh, \& Hau, 2008.

On the third page, first paragraph, first and second lines, Bradley, 1986; Bradley \& Hitch, 1994 should read Baddeley, 1986; Baddeley \& Hitch, 1994. Also on the third page, fourth paragraph, third line, Leong, 2007 should read Leong, Hau, Tse, \& Loh, 2007.

The corrected references in the reference list are as follows:

Baddeley, A. D. (1986). Working memory. London: Oxford University Press.

Baddeley, A. D., \& Hitch, G. J. (1994). Developments in the concept of working memory. Neuropsychology, 8, 485-493.

Cain, K., \& Oakhill, J. (1996). The nature of the relationship between comprehension skill and the ability to tell a story. British Journal of Developmental Psychology, 14, 187-201.

Daneman, M., \& Merikle, P. M. (1996). Working memory and language comprehension: A meta-analysis. Psychonomic Bulletin \& Review, 3, 422-433.

Ho, C. S. H., Chan, D. W. O., Tsang, S. M., \& Lee, S. H. (2000). The Hong Kong test of specific learning difficulties in reading and writing. Hong Kong: Hong Kong Specific Learning Difficulties Research Team.

Hoover, W. A., \& Tunmer, W. E. (1993). The components of reading. In G. B. Thompson, W. E. Tunmer, \& T. Nicholson (Eds.), Reading Acquisition Processes (pp.1-19). Clevedon: Multilingual Matters Ltd.

Leong, C. K., Hau, K. T., Tse, S. K., \& Loh, K. A. (2007). Component skills of text comprehension in less competent Chinese comprehenders. Annals of Dyslexia, 57, 75-97.

Leong, C. K., Tse, S. K., Loh, K. Y., \& Hau, K. T. (2008). Text comprehension in Chinese children: Relative contribution of verbal working memory, pseudoword reading, rapid automatized naming, and onset-rime phonological segmentation. Journal of Educational Psychology, 100(1), 135-149.

Leung, M. T. \& Lee, A. (2002). The Hong Kong Corpus of primary School Chinese. Paper presented at the 9th Meeting of the International Clinical Phonetics and Linguistics Association, Hong Kong.

McBride-Chang, C., \& Ho, C. S. H. (2005). Predictors of beginning reading in Chinese and English: a 2-year longitudinal study of Chinese kindergartners. Scientific Studies of Reading, 9, 117-144.

Muter, V., Hulme, C., Snowling, M. J., \& Stevenson, J. (2004). Phonemes, rimes, vocabulary, and grammatical skills as foundations of early reading development: Evidence from a longitudinal study. Developmental Psychology, 40(5), 665-681. 
Nation, K., \& Snowling, M. J. (2000). Factors influencing syntactic awareness skills in normal readers and poor comprehenders. Applied Psycholinguistics, 21(2), 229:41.

Oakhill, J. V., \& Cain, K. (2004). The development of comprehension skills. In T. Nunes \& P. Bryant (Eds), Handbook of Children's Literacy. Dordrecht: Kluwer Academic Publishers.

Oakhill, J., Cain, K., \& Yuill, N. (1998). Individual differences in children's comprehension skill: Toward an integrated model. In C. Hulme \& R. M. Joshi (Eds.), Reading and spelling: Development and disorders. Mahwah, NJ: Lawrence Erlbaum.

Perfetti, C. A. (1999). Comprehending written language: A blueprint of the reader. In C. M. Brown \& P. Hagoort (Eds.), The neurocognition of language. Oxford: Oxford University Press.

Perfetti, C. A., \& Hart, L. (2001). The lexical bases of comprehension skill. In D. Gorfien (Ed.), On the consequences of meaning selection. Washington DC: American Psychological Association.

Perfetti, C. A., Landi, N., \& Oakhill, J. (2005). The acquisition of reading comprehension skill. In M. J. Snowling \& C. Hulme (Eds.), The science of reading: A handbook. Oxford: Blackwell.

Pickering, S. J. (2006). Working memory in dyslexia. In T. P. Alloway \& S. E. Gathercole (Eds.), Working memory and neurodevelopmental disorders. Hove, UK: Psychology Press.

Roth, F. P., Speece, D. L., \& Cooper, D. H. (2002). A longitudinal analysis of the connection between oral language and early reading. Journal of Educational Research, 95, 259-272.

Shu, H., Anderson, R. C., \& Wu, N. (2000). Phonetic awareness: knowledge of orthography-phonology relationships in the character acquisition of Chinese children. Journal of Educational Psychology, 92, 56-62.

Shu, H., Anderson, R. C., \& Zhang, H. C. (1995). Incidental Learning of Word Meanings while Reading: a Chinese and American Cross-cultural Study. Reading Research Quarterly, 30(1), 76-95.

Stanovich, K. E. (1991). Word recognition: Changing perspectives. In R. Barr, M. L. Kamil, P. Mosenthal \& P. D. Pearson (Eds.), Handbook of Reading Research (Vol. 2). New York: Longman.

Swanson, H. L. (1999). Reading comprehension and working memory in learning-disabled readers: Is phonological loop more important than the executive system? Journal of Experimental Child Psychology, 72, 1-31.

Swanson, H. L. (2006). Working memory and reading disabilities: Both phonological and executive processing deficits are important. In T. P. Alloway \& S. E. Gathercole (Eds.), Working memory and neurodevelopmental disorders. Hove, UK: Psychological Press. 